\title{
Stress at work and mental health status among female hospital workers
}

\author{
M Estryn-Behar, M Kaminski, E Peigne, N Bonnet, E Vaichere, C Gozlan, S Azoulay, \\ M Giorgi
}

\begin{abstract}
Relations between working conditions and mental health status of female hospital workers were studied in a sample of 1505 women: $43 \%$ were nurses, $32 \%$ auxiliaries, and $7 \%$ ancillary staff; $13 \%$ were other qualified health care staff, mainly head nurses; $5 \%$ had occupations other than direct health care; $63 \%$ worked on the morning, $20 \%$ on the afternoon, and $17 \%$ on the night shift. Data were collected at the annual routine medical visit by the occupational health practitioner, using self administered questionnaires and clinical assessments. Five health indicators were considered: a high score to the general health questionnaire (GHQ); fatigue; sleep impairment; use of antidepressants, sleeping pills, or sedatives; and diagnosis of psychiatric morbidity at clinical assessment. Four indices of stress at work were defined: job stress, mental load, insufficiency in internal training and discussion, and strain caused by schedule. The analysis was conducted by multiple logistic regression, controlling for type of occupation, shift, number of years of work in hospital, daily travel time to work, age, marital status, number of children, and wish to move house. Sleep impairment was mostly linked to shift and strain due to schedule. For all other indicators of mental health impairment and especially high GHQ scores, the adjusted odds ratios increased significantly with the levels of job stress, mental load, and strain due to schedule. This evidence of association between work involving an excessive cumulation of stress factors and mental wellbeing should be considered in interventions aimed at improving the working conditions of hospital workers.
\end{abstract}

Assistance Publique, Mission Etudes et Information Santé-Travail, Ergonomie Hôtel-Dieu, 75004 Paris, France

M Estryn-Behar, E Peigne

INSERM U 149, 94807 Villejuif Cedex

M Kaminski

Assistance Publique, Médecine du Travail, Paris

N Bonnet, E Vaichere, C Gozlan, S Azoulay, M Giorgi
Since 1960, the use of medical time for anxiety and neurotic reactional states and psychogenic depression has been increasing. ${ }^{1}$ Work itself is not usually considered as the sole cause of psychic disorders but it may decompensate vulnerable states of psychic stability. The part of occupational life events in the occurrence of depression has received recent interest. ${ }^{2-4}$ Protecting mental wellbeing at work requires that general stressors be identified and the proportion of workers suffering from psychological or somatic stress reactions be known in order to develop adequate corrective and preventive actions. ${ }^{5}$

The work of women in hospital is a privileged field for studying the respective roles of working conditions and sociodemographic factors in the prevalence of mental and sleep disorders. These women represent nearly $9 \%$ of salaried female workers in France. ${ }^{6}$ Recent studies have shown that workers in occupations involving intense social contacts experience symptoms related to the loss of mental resources, known as the "burn out phenomenon." This phenomenon has often been described in health care occupations but only among one occupational group, nurses, and mainly in intensive care or paediatric units. ${ }^{7-9}$ Descriptive studies of the frequency of work stressors among hospital staff have been published ${ }^{10}$ and assessments of mental well being using the general health questionnaire (GHC) $)^{112}$ have been made among nurses ${ }^{13}$ and medical students. ${ }^{14}$ Comprehensive epidemiological studies analysing the relations between work stressors, sociodemographic factors, and stress level among health care personnel in various occupational categories have yet to be developed; and this is the aim of the present paper.

\section{Population and methods}

\section{SAMPLE AND DATA COLLECTION}

The present study is part of a general study of working conditions and health status of female hospital workers, which associates an epidemiological and an ergonomic approach. The protocol has been described in detail elsewhere ( $M$ Estryn-Behar, unpublished data); the main characteristics are summarised below.

The study was carried out in 12 public hospitals in the Paris area, all belonging to the same regional 
board; 26 departments were selected to cover all types of specialties except psychiatry. For each specialty, two departments were selected in two different hospitals. The sample considered for study included all female workers in post in these departments on 1 January 1986, except physicians. Data were collected at the annual routine medical visit with the hospital staff occupational health physician. Physicians are not covered by this surveillance system and thus could not be included in the study.

Data on occupation and working conditions, demographic and social characteristics, health status, treatments, and sick leave in the preceding 12 months were collected by a self administered questionnaire. Health status was also assessed by a clinical examination. Supplementary data on sick leave were obtained from administrative sources. The participation rate was $90 \%$ and data were finally collected for 1505 women. For the $10 \%$ of women missing, some basic information was available, including occupation and duration of sick leave.

Among the 1505 women, 21\% worked in paediatric or maternity departments, $30 \%$ in medical departments, $29 \%$ in surgical departments, $11 \%$ in intensive care units, and $9 \%$ in geriatric departments.

Ergonomic studies were conducted in 10 departments. ${ }^{15}$ In each department one nurse in each shift (morning, afternoon, and night) and one nursing aide on the morning or afternoon shift was followed up during the whole period. Interruptions and reorganisations of the work programme were recorded; discussions with patients, other members of staff, and doctors were recorded, as well as their duration; ambiguities, errors, and search for information could be observed in relation to work organisation, ways of transmitting information, and types of leadership; time spent in patients' rooms was measured.

Semistructured interviews of the workers were conducted at the end of each ergonomic study and the records were analysed by two psychiatrists.

\section{HEALTH INDICATORS}

Psychological disorders may take insidious forms such as tiredness, dizziness, headache, sleep problems, sexual troubles, aggressiveness, and psychosomatic disorders. After the stage of fatigue and dissatisfaction, the subject may present a major depressive disorder. In our context of primary care, to screen for unrecognised or early states of diseases that might develop into more important disorders, we used the following five indicators.

Fatigue-If the woman said she was waking up tired, if she was presently particularly tired, and if, in the previous 12 months, she had carried on working despite exhaustion, or if she had given at least two of these answers ( $32 \%$ of the women).

Sleep impairment-When the woman slept less than six hours on workdays, had regular sleep problems on workdays, and had regular sleep problems on rest days, or if she described at least two of these situations $(31 \%)$.

Use of drugs such as antidepressants, sedatives, or sleeping pills $(28 \%)$.

Psychiatric morbidity assessed by the occupational health physician at the routine medical visit (mostly depressive state or irritability) $(21 \%)$.

The $G H Q$ was used in its 12 item version..$^{12}$ Each item was rated on a four point scale, with weights from 0 to 3 . Scores higher than 12 were considered as an indicator of impaired mental wellbeing, and were found in $26 \%$ of the sample. Previous studies have validated the use of the GHQ in occupational communities ${ }^{1216}$ and in the present study the GHQ score was found to be highly correlated with the other mental health indicators (table 1): each was two to three times more frequent when the GHQ scores were high. A similar relation was found between GHQ scores and duration of absence from work for sickleave in the previous 12 months (table 1 ).

The GHQ score has also been analysed quantitatively (mean value 10.5 ); the results were similar to those obtained for the dichotomised variable but are not shown in this paper.

\section{OCCUPATION AND WORKING CONDITIONS}

The women were grouped into five occupational categories: $43 \%$ were nurses; $32 \%$ nursing aides; $7 \%$ ancillary staff; $13 \%$ were other qualified health care staff, mainly head nurses, but also midwives, physiotherapists, psychologists, and dieticians; and $5 \%$ had occupation other than direct health care (secretaries, laboratory technicians, social workers).

Sixty three per cent of women worked in the morning shift (beginning between 0600 and 0900), $20 \%$ in the afternoon shift (beginning between 1200 and 1530), and $17 \%$ in the night shift (beginning between 1800 and 2400).

Four indices of stress at work were defined to summarise the main characteristics of working conditions that may affect mental health status (see appendix for description of individual items included in the indices):

Table 1 Mental health indicators according to GHQ score ${ }^{\star}$

\begin{tabular}{|c|c|c|c|}
\hline & $\begin{array}{l}\text { GHQ score } \\
\leqslant 12 \\
(N o) \%\end{array}$ & $\begin{array}{l}\text { GHQ score } \\
>12 \\
(\mathrm{No}) \%\end{array}$ & p Value \\
\hline $\begin{array}{l}\text { Fatigue } \\
\text { Sleep impairment } \\
\text { Use of drugs } \\
\text { Psychiatric }\end{array}$ & $\begin{array}{r}1049) 23 \\
(991) 26 \\
(1047) 19\end{array}$ & $\begin{array}{l}(362) 56 \\
(355) 47 \\
(363) 44\end{array}$ & $\begin{array}{l}p<0.001 \\
p<0.001 \\
p<0.001\end{array}$ \\
\hline $\begin{array}{l}\text { examination } \\
10 \text { days sickleave } \\
\text { in the past } 12 \\
\text { months }\end{array}$ & $\begin{array}{l}(1017) 12 \\
(1044) 32\end{array}$ & $\begin{array}{l}(358) 55 \\
(361) 51\end{array}$ & $\begin{array}{l}\mathrm{p}<0.001 \\
\mathrm{p}<0.001\end{array}$ \\
\hline
\end{tabular}

$\star$ See definitions in text. 
An index of job stress, scoring 0 to 8 , including adequacy between training and actual tasks, relations with patients, interest in work, and satisfaction; $64 \%$ of women were at the lower level of job stress (score $0-1), 28 \%$ at the intermediate level (score $2-3$ ), and $8 \%$ at the higher level (score 4-8).

An index of mental load, in three levels, including interruptions in tasks, need of frequent reorganisation of daily work programme, and overwork: $18 \%$ of the sample were at the lower level, $62 \%$ at the intermediate level, and $20 \%$ at the higher level.

An index of insufficient internal training and discussion, scoring 0 to 5 , including teaching within the department, explanations about tasks, discussions of problems about relations with patients or organisation, and progress in job; this index had a lower level (score $0-1$ ) for $59 \%$ of women, an intermediate level (score 2-3) for 35\%, and a higher level (score 4-5) for $6 \%$.

An index of strain caused by schedule, scoring 0 to 3 , including number of consecutive working days and dissatisfaction with working hours; $13 \%$ of women were at the higher level (score 2-3).

Three other factors related to work were also considered: number of years since beginning work in hospital, daily time travelling between home and workplace, and an index of physical load of work including posture and heavy lifting.

\section{SOCIODEMOGRAPHIC FACTORS}

Factors known to be related to mental health were included as potential confounders: age, marital status, number of children at home, and wish to move house. ${ }^{217} 18$

\section{ANALYSIS}

The association between the health indicators and occupation, working conditions, and indices of job stress and sociodemographic factors was analysed, firstly, by crude comparisons, using Pearson's chi- squared test and, secondly, by multiple logistic regression. Adjusted odds ratios and $95 \%$ confidence intervals for the odds ratios were calculated for each occupational characteristic. Although similar analyses were conducted on the five mental health indicators, in some tables only fatigue, sleep impairment, and GHQ scores are shown. Because of missing data, numbers may vary according to the studied variable.

\section{Results}

Sick leave for mental and sleep problems caused 3080 days of sick leave among a total of 25433 days. This cause was the third. after musculoskeletal disorders and problems during pregnancy, and before respiratory and ENT diseases.

Fatigue and sleep impairment were more frequent among nursing aides and ancillary staff than in the other categories (table 2). There was no significant difference between occupational categories in the use of drugs or psychiatric morbidity at examination and no difference in GHQ scores. The only association observed with shift was a higher proportion of sleep impairments among night workers (table 2).

Although the level of stress varied greatly according to occupation (table 3 ), high levels were not always found in the same occupations. Job stress was especially high among ancillary staff and to a lesser degree among nursing aides, whereas mental load was high for nurses, other qualified health care staff, and other occupations. Insufficiency in internal training and discussion was mentioned more frequently by less qualified health care staff and by those in occupations other than health care. Strain due to schedule was found mostly in nurses and ancillary staff. Job stress and insufficiency in training and discussion did not vary according to the shift; the night shift was characterised by a significantly lower mental load and the afternoon shift by a high level of strain due to schedule (results not shown). All stress

Table 2 Mental health indicators according to occupational category and shift *

\begin{tabular}{|c|c|c|c|c|c|}
\hline & $\begin{array}{l}\text { Fatigue } \\
\text { (No) \% }\end{array}$ & $\begin{array}{l}\text { Sleep } \\
\text { impairment } \\
(\text { No }) \%\end{array}$ & $\begin{array}{l}\text { Use of } \\
\text { drugs } \\
\text { (No) \% }\end{array}$ & $\begin{array}{l}\text { Psychiatric } \\
\text { morbidity } \\
\text { at exam } \\
(\mathrm{No}) \%\end{array}$ & $\begin{array}{l}\text { GHQ score } \\
>12\end{array}$ \\
\hline $\begin{array}{l}\text { Occupation: } \\
\text { Nurses } \\
\text { Nursing aides } \\
\text { Ancillary staff } \\
\text { Other health care staff } \\
\text { Other occupations } \\
\text { p Value }\end{array}$ & $\begin{array}{c}(639) 29 \\
(479) 39 \\
(96) 44 \\
(185) 22 \\
(83) 31 \\
p<0.001\end{array}$ & $\begin{array}{r}(612) 29 \\
(455) 38 \\
(89) 38 \\
(175) 27 \\
(78) 13 \\
p<0.001\end{array}$ & $\begin{array}{l}(639) 23 \\
(479) 28 \\
(96) 31 \\
(186) 27 \\
(82) 22 \\
\text { NS }\end{array}$ & $\begin{array}{l}(621) 22 \\
(472) 18 \\
(94) 28 \\
(180) 21 \\
(81) 20 \\
\text { NS }\end{array}$ & $\begin{array}{l}(607) 27 \\
(444) 23 \\
(87) 28 \\
(176) 25 \\
(81) 28 \\
\text { NS }\end{array}$ \\
\hline $\begin{array}{l}\text { Shift: } \\
\text { Morning } \\
\text { Afternoon } \\
\text { Night } \\
\text { p Value }\end{array}$ & $\begin{array}{l}(923) 32 \\
(299) 32 \\
(252) 32 \\
\text { NS }\end{array}$ & $\begin{array}{l}(874) 27 \\
(280) 31 \\
(245) 51 \\
\mathrm{p}<0.001\end{array}$ & $\begin{array}{l}(922) 25 \\
(299) 26 \\
(253) 28 \\
\text { NS }\end{array}$ & $\begin{array}{l}(903) 20 \\
(291) 19 \\
(246) 25 \\
\text { NS }\end{array}$ & $\begin{array}{l}(872) 25 \\
(276) 25 \\
(238) 29 \\
\text { NS }\end{array}$ \\
\hline
\end{tabular}

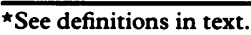


Table 3 Indices of stress at work (\%) according to occupational category ${ }^{\star}$ (number in parentheses)

\begin{tabular}{|c|c|c|c|c|c|c|}
\hline Occupation & Nurses & $\begin{array}{l}\text { Nursing } \\
\text { aides }\end{array}$ & $\begin{array}{l}\text { Ancillary } \\
\text { staff }\end{array}$ & $\begin{array}{l}\text { Other } \\
\text { health care }\end{array}$ & Other & p Value \\
\hline \multicolumn{7}{|l|}{ Shift: } \\
\hline Morning & 52 & 64 & 72 & 70 & 100 & \multirow{3}{*}{$\mathrm{p}<0.001$} \\
\hline Afternoon & 25 & 19 & 19 & 16 & 0 & \\
\hline Night & $\begin{array}{c}23 \\
(628)\end{array}$ & $\begin{array}{c}17 \\
(480)\end{array}$ & $\begin{array}{c}9 \\
(97)\end{array}$ & $\begin{array}{c}14 \\
(174)\end{array}$ & $\begin{array}{c}0 \\
(83)\end{array}$ & \\
\hline \multirow{2}{*}{\multicolumn{7}{|c|}{ Job stress: }} \\
\hline $0-1$ & 66 & 58 & 47 & 78 & & \multirow{4}{*}{$\mathrm{p}<0.001$} \\
\hline $2-3$ & 28 & 32 & 33 & 17 & 27 & \\
\hline $4-8$ & 6 & 10 & 20 & 5 & 9 & \\
\hline \multicolumn{6}{|l|}{ Mental load: } & \\
\hline Low & 13 & 20 & 36 & 14 & 12 & \multirow{3}{*}{$\mathrm{p}<0.001$} \\
\hline Average & 65 & 65 & 44 & 62 & 58 & \\
\hline High & 22 & 15 & 20 & 24 & 30 & \\
\hline \multicolumn{7}{|c|}{$\begin{array}{l}\text { Insufficiency in internal } \\
\text { training: }\end{array}$} \\
\hline training: & & & 43 & & & \multirow{4}{*}{$\mathrm{p}<0.001$} \\
\hline $2-3$ & 30 & 40 & 42 & 25 & $\begin{array}{l}30 \\
53\end{array}$ & \\
\hline $4-5$ & 4 & 9 & 15 & 3 & 9 & \\
\hline \multirow{4}{*}{$\begin{array}{l}\text { Strain due to schedule: } \\
0-1 \\
2-3\end{array}$} & (631) & $(472)$ & (93) & $(182)$ & (79) & \\
\hline & 82 & 90 & 83 & 93 & 96 & \multirow{3}{*}{$\mathrm{p}<0.001$} \\
\hline & 18 & 10 & 17 & 7 & 4 & \\
\hline & $(622)$ & (461) & (93) & (179) & (83) & \\
\hline
\end{tabular}

$\star$ See definitions in text.

indices were significantly related one with the other: table 4 shows that the higher the mental load, the insufficiency in training, or the strain due to schedule, the higher the job stress index was.

The frequency of all five mental health indicators increased significantly with the level of job stress (table 5); a similar trend was observed with mental load, although there was no association with sleep impairment. Fatigue, sleep impairment, and a GHQ score above 12 were more frequent when internal training and discussion were insufficient. Strain due to schedule was associated with an increased frequency of each health indicator. Similar results were found in each occupational category, as shown in table 6 for GHQ scores according to level of job stress.

Among the other occupational factors, no relation

Table 4 Job stress according to mental load, insufficiency in internal training, and strain due to schedule

\begin{tabular}{|c|c|c|c|c|}
\hline & \multicolumn{3}{|c|}{ Job stress } & \multirow[b]{2}{*}{ p Value } \\
\hline & $0-1$ & $2-3$ & $4-8$ & \\
\hline $\begin{array}{l}\text { Mental load: } \\
\text { Low }(n=250) \\
\text { Average }(n=907) \\
\text { High }(n=291)\end{array}$ & $\begin{array}{l}74 \\
66 \\
48\end{array}$ & $\begin{array}{l}22 \\
28 \\
34\end{array}$ & $\begin{array}{r}4 \\
6 \\
18\end{array}$ & $\mathrm{p}<0.001$ \\
\hline $\begin{array}{l}\text { Insufficiency in internal } \\
\text { training: } \\
0-1(n=855) \\
2-3(n=494) \\
4-5(n=90) \\
\text { Strain due to schedule: }\end{array}$ & $\begin{array}{l}73 \\
54 \\
30\end{array}$ & $\begin{array}{l}23 \\
33 \\
49\end{array}$ & $\begin{array}{r}4 \\
14 \\
21\end{array}$ & $\mathrm{p}<0.001$ \\
\hline $\begin{array}{l}0-1(n=1233) \\
2-3(n=291)\end{array}$ & $\begin{array}{l}67 \\
45\end{array}$ & $\begin{array}{l}26 \\
38\end{array}$ & $\begin{array}{r}7 \\
17\end{array}$ & $\mathrm{p}<0.001$ \\
\hline
\end{tabular}

was found between the number of years of work in hospital and the mental health indicators. The daily travel time was associated with fatigue (table 7) and the use of drugs (not shown) as well as the physical load of work with fatigue and the GHQ score.

Health indicators were not associated with marital status, except for psychiatric morbidity at clinical examination. Fatigue and sleep impairment were significantly more frequent when the number of children at home was higher (table 7); sleep impairment was also more frequent among older women. GHQ scores did not differ according to age or number of children but were higher among women wishing to move house.

To remove the potential confounding effect of the sociodemographic factors, multiple logistic regressions were carried out for each mental health indicator. The models included occupation, shift, the four stress indices, number of years of work in hospital, daily travel time, age, marital status, number of children at home, and wish to move house. As the physical load of work was found to be associated with mental health in the crude analysis, multiple logistic regression analyses were carried out both including and excluding this factor. Physical load never came out as significant in the models, and for the other factors the adjusted odds ratios were the same whether physical load was included or not, and the final analyses have not included this factor. Table 8 shows that; after adjustment, some differences appeared according to occupation: by comparison with nurses, nursing aides and ancillary staff were at a higher risk of fatigue and sleep impairment but nursing aides were at a lower risk for the GHQ score. 
Table 5 Mental health indicators according to indices of stress at work

\begin{tabular}{|c|c|c|c|c|c|}
\hline & $\begin{array}{l}\text { Fatigue } \\
(\mathrm{No}) \%\end{array}$ & $\begin{array}{l}\text { Sleep } \\
\text { impairment } \\
\text { (No) \% }\end{array}$ & $\begin{array}{l}\text { Use of } \\
\text { drugs } \\
\text { (No) \% }\end{array}$ & $\begin{array}{l}\text { Psychiatric } \\
\text { morbidity } \\
\text { at exam } \\
\text { (No) } \%\end{array}$ & $\begin{array}{l}\text { GHQ score } \\
(>12) \\
(\mathrm{No}) \%\end{array}$ \\
\hline $\begin{array}{c}\text { Job stress: } \\
0-1 \\
2-3 \\
4-8 \\
\text { p Value }\end{array}$ & $\begin{array}{r}(928) 25 \\
(409) 40 \\
(122) 58 \\
\mathrm{p}<0.001\end{array}$ & $\begin{array}{c}(875) 29 \\
(399) 32 \\
(118) 44 \\
p<0.01\end{array}$ & $\begin{array}{r}(926) 23 \\
(410) 24 \\
(122) 45 \\
\mathrm{p}<0.001\end{array}$ & $\begin{array}{r}(901) 16 \\
(402) 25 \\
(120) 43 \\
\mathrm{p}<0.001\end{array}$ & $\begin{array}{r}(874) 16 \\
(388) 35 \\
(118) 64 \\
\mathrm{p}<0.001\end{array}$ \\
\hline $\begin{array}{c}\text { Mental load } \\
\text { Low } \\
\text { Average } \\
\text { High } \\
\text { p Value }\end{array}$ & $\begin{array}{r}(261) 25 \\
(928) 30 \\
(297) 46 \\
p<0.001\end{array}$ & $\begin{array}{l}(247) 32 \\
(881) 31 \\
(283) 33 \\
\text { NS }\end{array}$ & $\begin{array}{r}(260) 23 \\
(928) 24 \\
(297) 34 \\
\mathrm{p}<0.001\end{array}$ & $\begin{array}{r}(258) 17 \\
(898) 20 \\
(293) 28 \\
\mathrm{p}<0.001\end{array}$ & $\begin{array}{r}(244) 12 \\
(878) 25 \\
(276) 39 \\
\mathrm{p}<0.001\end{array}$ \\
\hline $\begin{array}{c}\text { Insufficienc } \\
\text { training: } \\
0-1 \\
2-3 \\
4-5 \\
\text { p Value }\end{array}$ & $\begin{array}{r}(869) 29 \\
(508) 36 \\
(95) 41 \\
\mathrm{p}<0.01\end{array}$ & $\begin{array}{r}(827) 29 \\
(482) 34 \\
(94) 37 \\
\mathrm{p}<0.05\end{array}$ & $\begin{array}{l}(868) 25 \\
(508) 24 \\
(95) 33 \\
\mathrm{NS}\end{array}$ & $\begin{array}{r}(847) 20 \\
(495) 23 \\
(94) 22 \\
\mathrm{NS}\end{array}$ & $\begin{array}{c}(810) 22 \\
(490) 29 \\
(90) 42 \\
\mathrm{p}<0.001\end{array}$ \\
\hline $\begin{array}{l}\text { Strain due } t \\
0-1 \\
2-3 \\
p \text { Value }\end{array}$ & $\begin{array}{c}(1263) 30 \\
(188) 45 \\
\mathrm{p}<0.001\end{array}$ & $\begin{array}{r}(1204) 30 \\
(181) 40 \\
\mathrm{p}<0.01\end{array}$ & $\begin{array}{c}(1263) 24 \\
(188) 34 \\
\mathrm{p}<0.01\end{array}$ & $\begin{array}{r}(1232) 20 \\
(184) 29 \\
\mathrm{p}<0.01\end{array}$ & $\begin{array}{c}(1192) 23 \\
(183) 42 \\
\mathrm{p}<0.001\end{array}$ \\
\hline
\end{tabular}

A similar situation was found for shift: by comparison with the morning shift, women on the night shift were at a higher risk of sleep impairment, fatigue, and high GHQ scores. Sleep impairment was also more frequent for women in the afternoon shift and those with a high index of strain due to schedule.

Job stress, mental load, and strain due to schedule all remained significant risk factors for fatigue and high GHQ scores. The adjusted odds ratios for drug use or psychiatric morbidity at examination were also significantly increased according to the level of job stress (results not shown). On the whole, job stress, mental load, and strain due to schedule appeared as the most important occupational factors in mental health, sleep impairment being mostly affected by the shift. Among the sociodemographic factors, the number of children at home played the most important part, though leading to adjusted odds ratios lower than those obtained for the stress indices.

\section{Discussion}

Impaired wellbeing assessed by five mental health indicators was more frequent among health care staff

Table 6 Percentage of high GHQ scores according to job stress by occupation

\begin{tabular}{llllll}
\hline & \multicolumn{3}{l}{ Job stress } & \\
\cline { 2 - 5 } & $0-1$ & $2-3$ & $4-8$ & \\
Occupation & $(N o) \%$ & $(N o) \%$ & $(N o) \%$ & $p$ Value \\
\hline Nurses & $(394) 18$ & $(168) 40$ & $(39) 74$ & $\mathrm{p}<0.001$ \\
Nursing aides & $(248) 16$ & $(139) 24$ & $(44) 52$ & $\mathrm{p}<0.001$ \\
Auxiliary staff & $(38) 8$ & $(26) 38$ & $(17) 59$ & $\mathrm{p}<0.001$ \\
Other health care staff & $(134) 15$ & $(29) 45$ & $(10) 80$ & $\mathrm{p}<0.001$ \\
Other occupation & $(50) 16$ & $(21) 43$ & $(7) 57$ & $\mathrm{p}<0.01$ \\
\hline
\end{tabular}

when stress factors were at the highest level. The part of sociodemographic factors existed but inconsistently and leading to adjusted odds ratios lower than those obtained for the stress indices. For a high GHQ score, the adjusted odds ratio was 6.9 for the highest level of job stress, 2.9 for the highest level of mental load, and $2 \cdot 2$ for high strain due to schedule.

The participation rate was $90 \%$ and nonparticipants had a higher mean number of days of

Table 7 Mental health indicators according to demographic, social, and work characteristics

\begin{tabular}{|c|c|c|c|}
\hline & $\begin{array}{l}\text { Fatigue } \\
(\mathrm{No}) \%\end{array}$ & $\begin{array}{l}\text { Sleep } \\
\text { impairment } \\
(\text { No }) \%\end{array}$ & $\begin{array}{l}\text { GHQ score } \\
(>12) \text { No } \%\end{array}$ \\
\hline $\begin{array}{c}\text { Age }(y): \\
<40 \\
\geqslant 40 \\
\text { p Value }\end{array}$ & $\begin{array}{l}(1049) 32 \\
(442) 31 \\
\text { NS }\end{array}$ & $\begin{array}{l}(999) 29 \\
(418) 37 \\
\mathrm{p}<0.01\end{array}$ & $\begin{array}{l}(988) 25 \\
(416) 26 \\
\text { NS }\end{array}$ \\
\hline $\begin{array}{l}\text { No children at home: } \\
0 \\
1-2 \\
\geqslant 3 \\
\text { p Value }\end{array}$ & $\begin{array}{r}(625) 25 \\
(653) 36 \\
(195) 44 \\
p<0.001\end{array}$ & $\begin{array}{l}(597) 25 \\
(617) 33 \\
(189) 44 \\
p<0.001\end{array}$ & $\begin{array}{l}(599) 23 \\
(614) 27 \\
(177) 31 \\
\text { NS }\end{array}$ \\
\hline $\begin{array}{l}\text { Wish to move house: } \\
\text { No } \\
\text { Yes } \\
\text { p Value }\end{array}$ & $\begin{array}{l}(1018) 31 \\
(451) 34 \\
\text { NS }\end{array}$ & $\begin{array}{l}(980) 30 \\
(425) 35 \\
\text { NS }\end{array}$ & $\begin{array}{l}(954) 23 \\
(432) 31 \\
p<0.001\end{array}$ \\
\hline $\begin{array}{l}\text { Daily travel time: } \\
\leqslant 1 \mathrm{~h} 15 \\
>1 \mathrm{~h} 15 \\
\text { p Value }\end{array}$ & $\begin{array}{r}(887) 28 \\
(591) 38 \\
p<0.001\end{array}$ & $\begin{array}{l}(840) 30 \\
(568) 33 \\
\text { NS }\end{array}$ & $\begin{array}{l}(844) 25 \\
(552) 26 \\
\text { NS }\end{array}$ \\
\hline $\begin{array}{l}\text { Physical load of work: } \\
\text { Low } \\
\text { Average } \\
\text { High } \\
\text { p Value }\end{array}$ & $\begin{array}{r}(525) 27 \\
(532) 34 \\
(325) 41 \\
\mathrm{p}<0.001\end{array}$ & $\begin{array}{l}(504) 30 \\
(507) 33 \\
(306) 33 \\
\text { NS }\end{array}$ & $\begin{array}{l}(498) 23 \\
(502) 25 \\
(308) 31 \\
\mathrm{p}<0.05\end{array}$ \\
\hline
\end{tabular}

*Based on lifting and posture; see definition in text. 
Table 8 Mental health indicators according to occupation, shift, and stress at work: adjusted odds ratios ${ }^{\star}$

\begin{tabular}{|c|c|c|c|c|c|c|}
\hline & \multicolumn{2}{|l|}{ Fatigue } & \multicolumn{2}{|c|}{ Sleep impairment } & \multicolumn{2}{|c|}{ GHQ score $(>12)$} \\
\hline & $\begin{array}{l}O R \dagger \\
(n=1260)\end{array}$ & $95 \% \mathrm{CI}+$ & $\begin{array}{l}\text { OR† } \\
(n=1217)\end{array}$ & $95 \% \mathrm{CI} \ddagger$ & $\begin{array}{l}O R \dagger \\
(n=1203)\end{array}$ & $95 \% C I \ddagger$ \\
\hline \multicolumn{7}{|l|}{ Occupation: } \\
\hline Nurses & 1.0 & & $1 \cdot 0$ & & 1.0 & \\
\hline Nursing aides & 1.6 & $1 \cdot 1-2 \cdot 1$ & $1 \cdot 4$ & $1 \cdot 0-1 \cdot 9$ & 0.6 & $0.4-0.9$ \\
\hline Auxiliary staff & 1.6 & $0.9-2 \cdot 8$ & 1.9 & $1 \cdot 1-3 \cdot 4$ & 0.6 & $0 \cdot 3-1 \cdot 2$ \\
\hline Other health care & $0 \cdot 8$ & $0 \cdot 5-1 \cdot 3$ & $0 \cdot 8$ & $0.5-1 \cdot 3$ & $1 \cdot 3$ & $0 \cdot 8-2 \cdot 0$ \\
\hline $\begin{array}{l}\text { Other } \\
\text { Shift: }\end{array}$ & 1.5 & $0 \cdot 8-2 \cdot 7$ & 0.5 & $0 \cdot 2-1 \cdot 2$ & 1.5 & $0 \cdot 8-2 \cdot 8$ \\
\hline & \multicolumn{6}{|c|}{ Shift: } \\
\hline Afternoon & $1 \cdot 2$ & $0.8-1.7$ & 1.5 & $1 \cdot 0-2 \cdot 1$ & $\begin{array}{l}1.0 \\
0.9\end{array}$ & $0.6-1.4$ \\
\hline & \multicolumn{2}{|c|}{ Job stress: } & $3 \cdot 8$ & $2 \cdot 6-5 \cdot 5$ & $1 \cdot 6$ & $1 \cdot 1-2 \cdot 5$ \\
\hline $0-1$ & $1 \cdot 0$ & & 1.0 & & 1.0 & \\
\hline $\begin{array}{l}2-3 \\
4-8\end{array}$ & 1.6 & $1 \cdot 2-2 \cdot 2$ & $1 \cdot 0$ & $0 \cdot 7-1 \cdot 3$ & $2 \cdot 4$ & $1 \cdot 8-3 \cdot 4$ \\
\hline \multicolumn{7}{|l|}{ Mental load: } \\
\hline Low & 1.0 & & 1.0 & & $1 \cdot 0$ & \\
\hline Average & 1.5 & $1 \cdot 0-2 \cdot 1$ & $1 \cdot 1$ & $0 \cdot 7-1 \cdot 5$ & $2 \cdot 1$ & $1 \cdot 3-3 \cdot 3$ \\
\hline $\begin{array}{l}\text { High } \\
\text { Insufficiency in internal }\end{array}$ & $2 \cdot 6$ & $1 \cdot 6-4 \cdot 0$ & $1 \cdot 2$ & $0.8-1.9$ & $2 \cdot 9$ & $1 \cdot 7-4 \cdot 9$ \\
\hline \multicolumn{7}{|l|}{$\begin{array}{l}\text { Insufficiency in internal } \\
\text { training: }\end{array}$} \\
\hline $0-1$ & $1 \cdot 0$ & & 1.0 & & 1.0 & \\
\hline $2-3$ & $1 \cdot 1$ & $0 \cdot 8-1 \cdot 4$ & $1 \cdot 2$ & $0.9-1.7$ & 1.7 & $0 \cdot 8-1 \cdot 5$ \\
\hline \multirow{2}{*}{\multicolumn{7}{|c|}{ Strain due to schedule: }} \\
\hline & & & & & & \\
\hline $0-1$ & 1.0 & & $1 \cdot 0$ & & $1 \cdot 0$ & \\
\hline $2-3$ & $1 \cdot 4$ & $1 \cdot 2-2 \cdot 4$ & $1 \cdot 6$ & $1 \cdot 1-2 \cdot 4$ & $2 \cdot 2$ & $1 \cdot 4-3 \cdot 2$ \\
\hline
\end{tabular}

${ }^{\star}$ Adjusted for age, marital status, number of children at home, wish to move house, number of years of work in hospital, and daily travel time in a multiple logistic regression.

tAdjusted odds ratio.

$\$ 95 \%$ Confidence interval for the adjusted odds ratio.

sick leave (34 days). Reasons for non-participation were difficulties in examining women on the night shift $(31 \%)$ and long sick leave $(42 \%)$-mostly due to problems during pregnancy $(18 \%)$. The occupational levels of participants and non-participants did not differ significantly. The high response rate combined with the anonymity guaranteed to all respondents gives no reason for rejecting the results on the grounds of reliability. As in any cross sectional study some possible bias has to be considered. Self selection out of work of those exposed to the most stressful situations, leading to a healthy worker effect, may have minimised some relations between health and working conditions; however, the observed relations are strong. The answers on working conditions may have been influenced by the mental health status at the time of survey, thus overestimating certain associations. Questions about working conditions, however, were asked first in the questionnaire before any health parameter.

Some of the work stress indices were validated through an ergonomic study. At group level the ergonomic observations gave descriptions of the work that were consistent with that observed from the questionnaires. ${ }^{15}$ The time spent with patients did not differ between nursing aides and nurses but the basic knowledge of nursing aides was not the same and their discussions with physicians were more exceptional, thus explaining their higher level of job stress and of insufficiency of internal training and discussion. The number of interruptions during tasks was higher in day observations than in night shifts, but the higher number of patients per nurse during night shift is consistent with a lower level of mental load only for the afternoon shift.

Five mental health indicators were considered in order to approach, so far as possible, the presence or absence of psychological stress. The consistency of the relations between working conditions and the five mental health indicators increased the viability of the data collected, overcoming semeiological problems of diagnosis when made by primary care practitioners and not psychiatrists. Especially for fatigue we must question the possibility of an inverse relation: the fatigue leading to a negative judgment on work instead of adverse working conditions leading to fatigue. But the observation of relations between fatigue and insufficiency of internal training and discussion, which is much less subjective, reinforced the relations between fatigue and job stress. The reliability of the mental health indicators is reinforced by the analysis by psychiatrists of the semistructured interviews after the ergonomic observations: they concluded that the content of the interviews suggested a dysphoric state of mind, linked to isolation of the staff members and lack of reinforcement for the tasks performed. ${ }^{19}$ In our study overall fatigue was noted by $32 \%$ of the women. The 
morbidity at medical examination was higher than the one observed by a national study of morbidity among French active women. In Sweden Joenpelto and Vahanen found general fatigue among $16 \%$ of health workers. ${ }^{20}$ Burn out is described by Maslach and Pines as a highly insidious process with a three phase sequence in the first of which health care workers feel an emotional exhaustion, resulting from prolonged intensive involvement with patients, in which just thinking of having to go to work makes them tired. $^{21}$ For Cherniss, this first stage of imbalance between resources and demand produces strain in the worker, manifested as feelings of tension, irritability, and fatigue. ${ }^{22}$ It is necessary to act at this phase to avoid entering in a cycle of failure difficult to break.

Strain due to schedule and schedule itself of our sample could be compared with that of a national sample of salaried women in a survey using similar questions (MF Christofari, unpublished data); the comparison showed a higher frequency of work, more than 100 nights a year $(16 \%$ instead of $2 \%)$, of work early in the morning or late in the afternoon (respectively $38 \%$ instead of $12 \%$ and $20 \%$ instead of $7 \%$ ), of consecutive working days without rest (35\% instead of $66 \%$ worked five days or fewer at a stretch). By contrast, job motivation seemed to be high among health care staff, as only $3 \%$ found their job without interest whereas $22 \%$ of the national sample found their job repetitive. In this national survey the subsample of women working in hospitals differed from the other salaried women on these working conditions. Women working in the hospitals belonging to the regional board studied, however, were exposed to a higher level of strain due to schedule but had a higher job motivation. The strain caused by schedule and night work necessitate also a specific attention. ${ }^{23}{ }^{24}$ Chronobiological knowledge must be integrated in organisation of worktime to avoid performance impairments such as those studied by Poulton et al. ${ }^{25}$

The positive impact of counselling and discussion between staff members and with physicians has been focused in case studies by numerous authors. ${ }^{26-28}$ Some of them have discussed the role of staff support groups. ${ }^{29-33}$ Others have exposed the benefit of group meetings with an outsider trained in psychology. ${ }^{34-36}$ Fawzy et al showed that the involvement of the psychiatric liaison in four services led to high job satisfaction, task orientation, and reduced turnover compared with a department without similar support. ${ }^{37}$

The head nurse can develop an atmosphere in which staff members are encouraged to identify stress factors in the environment and learn from mistakes. The head nurse can use report times to discuss psychological issues relative to patients. 38 The simple provision of specific workshops, refre- sher courses, and establishment of consensus on protocols and techniques in use in the department is of great use to alleviate anxiety. ${ }^{40}$ Bishop has insisted on the necessity that criteria for treatment or nontreatment should be clearly discussed. ${ }^{41}$ Other authors have proposed preceptorships to help new graduates to acquire a role model and a resource person within the clinical setting to help new staff members to adjust to their jobs and also experienced nurses moving into a different specialty. ${ }^{42-45}$ Vachon et al trained a staff member to be a resource person for all the staff about psychological problems. ${ }^{13}$

Leppanen and Olkinuora have reviewed the epidemiological studies on stress problems among Scandinavian health care personnel. ${ }^{10}$ Insufficiency in training was also found: Gardel et al showed that nearly half of the nurse's aides thought that their medical knowledge was insufficient for their work demands. ${ }^{46}$ Every fourth practical nurse, every fifth registered nurse, every tenth head nurse, and every seventh physician considered themselves to be incompetent in medical questions; incompetence concerning psychological issues was experienced even more often: in particular the practical nurses and nurse's aides who spend more time with patients than other professionals thought themselves to be incompetent in psychological issues.

Several studies reviewed by Leppanen and Olkinuora deal with role conflicts and role ambiguity ${ }^{10}$ : Joenpelto and Vahanen showed that nearly half of the surgical ward nurses reported that they were unfamiliar with some of their duties. ${ }^{20}$ They also thought that the conflicting expectations and demands of patients and other staff members caused them strain; Jokinen and Poyhonen noted that only one out of five practical nurses in Helsinki was always aware of tasks to be done and the aims of their work. ${ }^{47}$

Meeting the medical and emotional needs of ill patients is a major source of stress but there are other causes. The hospital workers are involved in a chain of command that makes them a likely target for the release of frustrations by physicians, supervisors, and co-workers, as well as patients and their families. But there are few opportunities for them to deal with these frustrations. If the health workers are experiencing personal problems unrelated to their work the stress is exacerbated. Improved communication and learning to manage the stresses are likely to result in a better interpersonal climate in which patients' emotional comfort could be nurtured. The medical director of the department and the head nurse must devote time to improving communication, as is the main wish of those interviewed ${ }^{19}$ and, maybe, change some of the rules of the doctor-nurse game as stated by Thomstad et al. ${ }^{48}$

In the present state of knowledge further aetiological studies, primarily cohort studies, are needed to understand better the role of work and 
work stresses in mental health. Intervention studies are even more necessary, to evaluate the effectiveness of the measures discussed above, to occupations.

We thank C Berthier, M F Delaporte, A Lefevre, J M Leroux, M Louet, M F Maillard, G Melonio, M C Paoli, Mrs C Blanpain, N Carlin, and M Gayet for their collaboration and Mrs S Closon, G Gamarre, C Girier-Desportes, D Larcher, and M Somveille for technical support. The research was partly supported by a grant from the Institut National de la Santé et de la Recherche Médicale (contrat de recherche AP No 858011).

\section{Appendix}

INDEX OF JOB STRESS: number of the following items Does your job correspond to your level?

seldom or never

Do you do work for which you are not trained?

always

Have you enough time to talk to patients?

not enough or very insufficient

Are you well prepared to answer their questions?

often doubt or worry about answer

Are you satisfied with atmosphere in present

department? No

Do you find your job interesting?

variable or not interesting

In your opinion, atmosphere in your department is? rather bad

Has your work an effect on your mood outside?

frequently rather bad

INDEX OF MENTAL LOAD:combination of the following items

Are you interrupted in your tasks?

No-rarely

Sometimes

Often

Have you to reorganise your work programme

many times during the day?

No-rarely

Often

Always

Do you feel overworked in your job?

No

A little

Yes

INDEX OF INSUFFICIENCY IN INTERNAL TRAINING AND DISCUSSION: number of the following items

Are teaching sessions organised in your department? Never

Do you get explanations about tasks which you are asked to do?

Not at all

Are there opportunities to discuss problems related to organisation?

No

Are there opportunities to discuss relations or

psychological difficulties with patients?

No

Do you feel you are progressing in your job?

Not at all or regressing

INDEX OF STRAIN CAUSED BY SCHEDULE: number of the following items

Work more than six consecutive working days

Has asked or would ask to begin work earlier or later

Is not satisfied with schedule

$(18 \%)$

1 Pichot $\mathrm{P}$, Boyer $\mathrm{P}$, Zarifian E, et al. La maladie dépressive. Paris: Laboratoires Ciba-Ceigy, 1983.

2 Brown GW, Davidson S, Harris T, et al. Psychiatric disorders in London and North West. Soc Sci Med 1977;11:367-77.

3 Lloyd C. Life events and depressive disorders reviewed. Arch Gen Psychiatry 1980;37:529-48.

4 Ferreri M, Vacher J, Alby JM. Facteurs évenementiels et dépressions: le questionnaire EVE. Une nouvelle approche de méthodologie prédictive. Psychologie Médicale 1987;19: 2441-8.

5 Kalimo R, El-Batawi MA, Cooper C. Psychosocial factors at work and their relation to health. Geneva: World Health Organisation, 1987.

6 Institut National de la Statistique et des Etudes Economiques. Etude particulière à partir de l'enquête emploi. Paris: INSEE, 1988. (Série D 128.)

7 Jacobson S. Stressful situations for neonatal intensive care nurses. American Journal of Maternal Child Nursing 1978;3:144-50.

8 Estryn-Behar M, Mascolo I. Psychopathologie du travail des professions paramédicales dans un service de réanimation médicale. Psychologie médicale 1983;15:289-94.

9 Appelbaum SH. Stress management for health care professionals. Rockville, Maryland: Asper Publishers, 1981.

10 Leppanen RA, Olkinuora MA. Psychological stress experienced by health care personnel. Scand $J$ Work Environ Health 1987;13:1-8.

11 Goldberg $D$. The detection of psychiatric illness by questionnaire. London: Oxford University Press, 1972.

12 Banks MH, Clegg CW, Jackson PR, Kemp NJ, Stafford EM, Wall TD. The use of the general health questionnaire as an indicator of mental health in occupational studies. Journal of Occupational Psychology 1980;53:187-94.

13 Vachon MLS, Lyall WA, Freeman SHF. Measurement and management of stress in health professional working with advanced cancer patients. In: Death education. Washington: Hemisphere, 1978:365-75.

14 Firth J. Levels and sources of stress in medical students. Br Med J 1986;292:1177-80.

15 Estryn-Behar M, Kaminski M, Peigné E, Fouillot JP, Debray Q. Concevoir une architecture et une organisation pour la santé et la sécurité à l'hôpital. In: Proceedings of seminar on building for people in hospital: workers and consumers. Dublin: European Foundation for the Improvement of Living and Working Conditions (in press).

16 Rahman M, Sen AK. Effect of job satisfaction on stress, performance and health in self-paced repetitive work. Int Arch Occup Environ Health 1987;59:115-21.

17 Weissman MM, Myers JK. Rates and risks of depressive symptoms in a United States urban community. Acta Psychiatr Scand 1978;57:219-31.

18 Hirschfeld RMA, Cross CK. Epidemiology of affective disorders psychological risk factors. Arch Gen Psychiatry 1982;39:35-46.

19 Debray Q, Estryn-Behar M, Guillibert E, Azoulay S, Bonnet N. Les conditions de travail du personnel hospitalier féminin: les aspects psychologiques. Psychiatrie et Psychobiologie 1988;3:389-99.

20 Joenpelto L, Vanhanen K. In: Leppanen and Olkinuora. ${ }^{10}$ 
21 Maslach C, Pines A. The burn out syndrome in the day care setting. Child Care Quarterly 1977;6:100-13.

22 Cherniss C. Staff burn out: job stress in the human services. London: Sage Publications Beverly Hills, 1980.

23 Estryn-Behar M. Capacités de travail, mémoire et rythmes circadiens. Bilan des études réalisées dans le domaine du travail de nuit des personnels hospitaliers. Santé Publique, numéro spécial "Mémoire et mémoires en Santé Publique" 1989;4:105-13.

24 Direction du personnel, CHSCT Central, CHSCT Locaux. Etude sur le travail de nuit. Paris: Assistance Publique Hôpitaux de Paris, 1988.

25 Poulton EC, Hunt GM, Carpenter A, Edward RS. The performance of junior hospital doctors following reduced sleep and long hours of work. Ergonomics 1978;21:279-95.

26 Rossini LA, Howell MC, Todres ID, Dorman J. Group meetings in a pediatric intensive care unit. Pediatrics 1974;53:371-4.

27 Joly JB, Richard P, Baudet MT. Chronique de pédiatrie sociale. Les relations entre parents-enfants et personnel soignant dans un centre de néonatologie. Pédiatrie 1976; XXXI:603-13.

28 Strain JJ. Psychological reactions to acute medical illness and critical care. Crit Care Med 1978;6:39-44.

29 MacGrath HM. Mediating stress through support networks. In: Jacobson SF, MacGrath HM, eds. Nurses under stress. New York: John Wiley, 1983:194-208.

30 Gonin O. L'agressivité dans les équipes soignantes. Krankenpflege/ Soins Infirmiers 1984;4:68-9.

31 PolettiR. Que peut-on faire de positif avecl'agression? Krankenpflege/Soins Infirmiers 1984;4:61-2.

32 Verspieren P. Face à celui qui meurt. Paris: Desclee de Brower, 1984.

33 Zumbrunnen $R$. Quand un patient peut-il se montrer agressif et que peut l'équipe soignante à l'hôpital général? Krankenpflege| Soins Infirmiers 1984;4:71-3.

34 Price TR, Bergen BJ. The relationship to death as a source of stress for nurses on a coronary care unit. Omega 1977;8: 229-38.
35 Sebag-Lanoé $\mathrm{R}$, Virguie $\mathrm{Cl}$, Cazas $\mathrm{A}$. Le travail en équipe en gériatrie: un apprentissage indispensable pour le médecin. Médecine et Hygiene 1982;40:1842-6.

36 Zittoun R. Une communauté pour en parler. In: Entretiens avec E. Hirsch. Partir. L'accompagnement des mourants. Paris: Cerf, 1986:1-14.

37 Fawzy IF, Wellisch DK, Pasnau RO, Leibowitz B. Preventing nursing burn-out: a challenge for liaison psychiatry. General Hospital Psychiatry 1983;5:141-9.

38 Kornfeld DS. Psychiatric view of the intensive care unit. $\mathrm{Br} \mathrm{Med}$ J 1969;i:108-10.

39 Simon NM, Whitely S. Psychiatric consultation with MICU nurses: the consultation conference as a working group. Heart Lung 1977;6:497-504.

40 Bilodeau CB. The nurse and her reactions to critical-care nursing. Heart Lung 1973;2:358-63.

41 Bishop V. Stress in the intensive care unit. Occupational Health 1983;35:537-43.

42 Dell MS, Griffith E. A preceptor programme for nurses' clinical orientation. J Nurs Adm 1977;7:37-8.

43 Chickerella BG, Lutz WJ. Professional nurturance: perceptorships for undergraduate nursing students. Am $J$ Nurs 1981;1:107-9.

44 Murphy ML, Hammerstad SM. Preparing a staff nurse for precepting. Nurse Educator 1981; Sept-Oct: 17-20.

45 Jacobson SF, MacGrath HM. Nurses under stress. New York: John Wiley, 1983.

46 Gardell B, Gustafason RA, Brandt C, Tillstrỏm I, Torbiöun I In: Leppanen and Olkinuora. ${ }^{10}$

47 Jokinen M, Poyhonen T. In: Leppanen and Olkinuora. ${ }^{10}$

48 Thomstad B, Cunningham N, Kaplan BH. Changing the rules of the doctor-nurse game. Nurs Outlook 1975;23:422-7.

Accepted 13 February 1989 